\title{
Characterization of mechanical damage in coffee seeds by the LERCAFÉ test ${ }^{1}$
}

\author{
Caracterização de danos mecânicos em sementes \\ de cafeeiro pelo teste LERCAFÉ \\ João Batista Zonta ${ }^{2}$,Eduardo Fontes Araújo ${ }^{3}$, Roberto Fontes Araújo ${ }^{4}$, \\ Flávia Miranda Garcia Zonta ${ }^{3}$, Múcio Silva Reis ${ }^{3}$
}

\section{SUMMARY}

The present work aimed at evaluating the use of the LERCAFÉ test to estimate germination and characterize mechanical damage in coffee seeds. The experiment was conducted in the Laboratory of Seed Research at the Universidade Federal de Viçosa, Viçosa-MG. Coffea arabica seeds were submitted to the following treatments: Lot 1 (0\% of damaged seeds), Lot 2 (5\% of damaged seeds), Lot 3 (10\% of damaged seeds) and Lot 4 (15\% of damaged seeds). The mechanical damage was caused with the use of the Pulverisette 14 (Fritsch) apparatus. The damage was caused randomly and individually in the seeds, and the lots proportionally combined undamaged and damaged seeds, totaling 1600 seeds per lot. The seeds were evaluated by the germination and LERCAFÉ tests. For this type of damage, the germination results achieved by the LERCAFÉ test presented high correlation with those achieved by the germination test $(\mathrm{r}=0,9550)$. Although being randomly caused in the seeds, in other words, without reaching a pre-determined region, the mechanical damage was always characterized by a breach in the embryo region and/or in the region opposite to the embryo and the edges of these breaches presented a green stain. The LERCAFÉ test was efficient to estimate germination and characterize mechanical damage in coffee seeds. Lots of seeds mechanically damaged presented a sharp decrease in the germination power.

Key words: fast test, sodium hypochlorite, Coffea arabica.

\section{RESUMO}

Objetivou-se neste trabalho avaliar a utilização do teste LERCAFÉ para estimar a germinação e caracterizar danos mecânicos em sementes de cafeeiro. O experimento foi conduzido no Laboratório de Pesquisa de Sementes da Universidade Federal de Viçosa, Viçosa-MG. Utilizaram-se sementes de cafeeiro arábica, submetidas aos seguintes tratamentos: Lote 1 (0\% de sementes danificadas), Lote 2 (5\% de sementes danificadas), Lote 3 (10\% de sementes danificadas) e Lote 4 (15\% de sementes danificadas). Os danos mecânicos foram provocados com uso de equipamento Pulverisette 14 (Fritsch). O dano foi causado individualmente nas sementes, ao acaso, e os lotes foram obtidos misturando-se proporcionalmente sementes sem dano com sementes danificadas, num total de 1600 sementes por lote. As sementes foram avaliadas pelos testes de germinação e LERCAFÉ. Para este tipo de dano, os resultados de germinação obtidos pelo teste LERCAFÉ apresentaram alta correlação com os obtidos pelo teste de germinação $(r=0,9550)$. O dano mecânico, apesar de ter sido provocado ao acaso nas sementes, ou seja, sem atingir uma região pré-determinada, caracterizou-se sempre por uma fenda na região do embrião elou na região oposta ao embrião, aparecendo, nas bordas destas aberturas, uma mancha de coloração verde. O teste LERCAFÉ foi eficiente para estimar a germinação e caracterizar danos mecânicos em sementes de cafeeiro. Lotes de sementes danificadas mecanicamente apresentaram queda acentuada no poder germinativo.

Palavras-chave: teste rápido, hipoclorito de sódio, Coffea arabica.

\section{Introduction}

The coffee seed preparation process may cause damage and lower the quality of the seeds, since it is generally carried out with humid seeds in apparatuses, in which the exocarp and mesocarp are removed from the fruit through friction and attrition. Therefore, it is indispensable to use fast

1 Part of the masters dissertation of the first author

2 Embrapa Cocais, Av. Santos Dumont, nº18, Anil, 65046-660, São Luis-MA, e-mail: joao.zonta@embrapa.br

3 Universidade Federal de Viçosa, Avenida Peter Henry Rolfs, s/n Campus Universitário 36570-000 Viçosa, MG.

E-mail: efaraujo@ufv.br, flaviaufv@gmail.com, msreis@ufv.br

4 Epamig, Vila Gianneti, № 47 Campus Universitário 36570-000 Viçosa, MG. E-mail: rfaraujo@ufv.br

Fecha de Recepción: 30 Marzo, 2010.

Fecha de Aceptación: 18 Enero, 2011. 
tests to identify the mechanically damaged seeds, as part of the company's program of quality control, which will allow the necessary adjustments in the harvest and processing methods (Vieira et al., 1998).

Carvalho and Nakagawa (2000) and Bewley and Black (1994) define the mechanical damage as the damage caused by physical agents during the harvest, processing, storage, transport and planting procedures, producing attrition, cracks, cleavage and breakage in the seeds, with a direct correlation with the reduction of germination, emergence and vigor, as well as the storage potential of the seeds. According to Coutinho (1984) and Carvalho and Nakagawa (2000), the mechanical damage in seeds result from external forces which are higher than their resistance, causing cell ruptures by shear force or the combination of several forces, and the injuries may be difficult to be diagnosed and/or quantified, mainly due to the viscoelastic behavior of seeds. Mechanical damage is extremely harmful to the quality of coffee seeds. In a study carried out by Araujo et al. (2004), the mechanical damage of coffee seeds, caused by the parchment removal in palette scarifier, resulted in the total loss of seed germination by the sand emergence test. Fagundes et al. (2009) observed that coffee seeds mechanically damaged by the use of peeling machine present impaired germination, and that significant lower germination values are found when they are compared to the germination achieved by the unharmed seeds.

Due to the great impact of damage on the loss of seed viability, some tests are used to detect and quantify it. Nowadays, the most common tests are the fast green and the iodine dyeing for maize seeds (Marcos Filho et al., 1987), the tetrazolium test for soybean seeds, and the analysis of digital image and $\mathrm{x}$-ray for several species (Oliveira, 2000; Battisti et al., 2000; Machado, 2002; Flor et al., 2004). Menezes (2007) concluded that, for seeds of soybean, beans and other legumes, the identification of the mechanical damage can be performed by means of the test in immersion in sodium hypochlorite. In this test, the seeds are imbibed in a solution of sodium hypochlorite at $5 \%$ for 10 minutes, after which they are drained and placed on paper towel. Next, the solution is drained and the seeds are distributed on the paper towel, where they are individually examined, for the determination of the percentage of damaged seeds. The damaged seeds intumesce when they absorb the solution, while the uninjured seeds preserve their original condition.
For coffee seeds, Vieira et al. (1998) used tetrazolium solution to determine mechanical damage. The damaged endosperm region presented red color. Nevertheless, the tetrazolium test has some disadvantages, such as high cost and the need for a trained professional to perform a correct evaluation.

In a study carried out with coffee seeds, Reis (2004) verified that the LERCAFÉ test is efficient to estimate their viability. This test involves the imbibition of the seeds in a solution of sodium hypochlorite, in the concentration of $2,5 \%$ of the active chlorine, for 3 hours at $25^{\circ} \mathrm{C}$. In these studies, the author verified that certain concentrations of sodium hypochlorite used as imbibition solution react with deteriorated parts of the endosperm, causing the appearance of a green coloration in these areas. By studying the use of the LERCAFÉ test to identify damage in coffee seeds, Zonta et al. (2008) and Zonta et al. (2009) characterized different types of injuries with this test. The damage caused by the coffee berry borer and by high temperature drying was characterized by regions with greenish color in the injured area, while the natural aging during storage caused the darkening of the seed endosperm. Thus, similarly to the tetrazolium test, it is believed that the LERCAFÉ test can be used to characterize, by means of that color, the occurrence of mechanical damage in coffee seeds. Besides, the test proved to be very promising due to its low cost, low demand for labor force and easy performance and result interpretation.

Considering the impact of mechanical damage on the quality of seeds and the practicality of the LERCAFÉ test, the objective of the present work was to characterize mechanical damage in coffee seeds by means of this test.

\section{Material and methods}

The experiment was conducted at the Seed Research Laboratory of the Federal University of Viçosa, in Viçosa - MG. The coffee seeds (Coffea arabica L.), cultivar IAC Catuaí 44, from the Experimental Farm Vale do Piranga/Agricultural Research Company of Minas Gerais (EPAMIG). Fruits were handpicked at cherry stage. After harvesting, fruits were depulped and fermented in water for 24 hours and washed for mucilage removal. The seeds were washed in tap water and spread on a screen in the shade to remove excess moisture. Seeds were then dried in $10 \times 15 \mathrm{~cm}$ muslin bags 
containing approximately 1.3 kilograms each, in the shade, to $33 \%$ moisture levels (wet basis). The mechanical damage was provoked with the use of the Pulverisette 14 apparatus (Fritsch). The damage was caused individually in the seeds. Each seed was submitted to only one blow in the apparatus, since it had a lateral cavity in which the seeds were placed after receiving the damage. The lots were obtained by the proportional mixture of undamaged and damaged seeds, totaling 1600 seeds per lot. The treatments consisted of damaged seeds, at the following percentages: $0 \%$, lot $1 ; 5 \%$, lot $2 ; 10 \%$, lot 3 ; and $15 \%$, lot 4 .

The seeds of each treatment were evaluated by the LERCAFÉ and Germination tests.

LERCAFÉ Test. Four repetitions of 50 seeds per treatment, with parchment manually removed. Using gerboxes with plastic screen, for complete soaking of seeds with sodium hypochlorite solution, $2.5 \%$ active chlorine, using $100 \mathrm{~mL}$ of the solution per 50 seeds, or corresponding volume. The gerboxes were placed in a BOD incubator, at $25^{\circ} \mathrm{C}$, for 3 hours. Seeds were then washed in tap water for 90 seconds, soaked in distilled water for 40 minutes, and fi nally placed on a bench for evaluation. Following the visual evaluation, seeds were photographed and the percentages of germinable and non-germinable seeds were calculated as a function of endosperm colour and presence of embryo, according to methodology described by Reis (2004).

Germination test. Two hundred seeds with parchment manually removed were sown on germitest towel paper (3 layers) moistened with distilled water in quantities equivalent to 2.5 times the dry weight of the paper, with four repetitions. The rolls were kept in the incubator at $30^{\circ} \mathrm{C}$. Evaluations took place 15 and 30 days after sowing, and the results were expressed in mean percentage of normal seedlings (Brasil, 1992).

The experiment was arranged in a complete randomized design, with four repetitions. The data were submitted to the analysis of variance and the averages were compared by the Tukey test at 5\% of probability. Pearson's coefficient of correlation between LERCAFÉ and germination tests was calculated, and the significance of correlation was determined by the t-test at $1 \%$ probability (Gomes, 2000).

\section{Results and discussion}

After the LERCAFÉ test was carried out in the lots with different percentages of damaged seeds, the seeds with different visual characteristics were observed. Thus, for the determination of the viability of the lots, they were divided into 3 classes (Figure 1). The seeds of the class 1, classified as
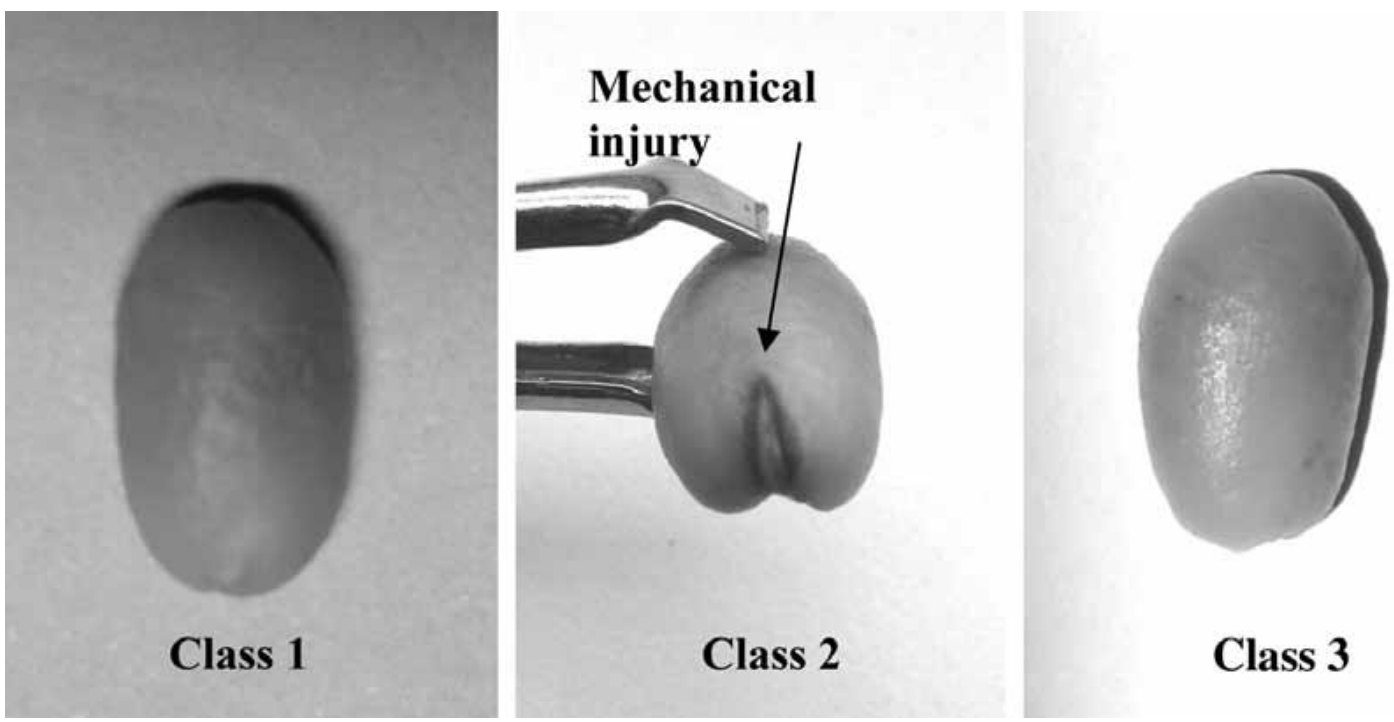

Figure 1: Classification of coffee seeds by the LERCAFÉ test.

Class 1 - Seed with endosperm presenting light color and visible embryo (germinable);

Class 2 - Seed with endosperm presenting light color and typical mechanical damage lesion (non-germinable);

Class 3 - Seed with endosperm presenting light color, but no visible embryo (non-germinable). 
germinable, presented endosperm with light color and visible embryo. The seeds of the class 2 presented typical mechanical damage lesions. This damage was characterized by a breach in the embryo region and, sometimes, also in the region opposite to the embryo, with a stain in the edges of these breaches. The seeds of the class 3 presented endosperm with light color, without visible (or absent) embryo. Seeds belonging to the classes 2 and 3 were considered nongerminable. The characterization of different types of damage in coffee seeds by the LERCAFÉ test has already been described by Zonta et al. (2008). These authors characterized the damage by high temperature drying and the damage by coffee berry borer. The first one was characterized by the occurrence of green stains spread in the seed endosperm, either partially or completely; the second was characterized as a depression surrounded by a green ring.

The Table 1 presents the germination values achieved by the germination test, and the different classes of seeds, according to the LERCAFÉ test, for all the lots studied.

Observing the values of the different classes achieved by the LERCAFÉ test, it can be observed that the test was efficient to detect the difference in the percentage of germination among the lots, since the percentage of seeds of the class 1, classified as germinable, varied among the lots, corresponding to the values found by the germination test.

By analyzing the percentage of seeds found in the class 2, which corresponds to the seeds with mechanical damage, it is possible to observe that this damage significantly affected the germination of the seeds, since lots 3 and 4, which presented higher percentages of seeds of the class 2 , decreased their germination to 85 and $81 \%$, respectively, by the germination test. The lots 1 and 2, which presented lower amounts of seeds of the class 2, did not differ significantly.

The decrease in the germination of a lot of coffee seeds with higher incidence of mechanical damage demonstrates that it was detrimental to their germination. Araújo et al. (2004), studying the incidence of mechanical damage in coffee seeds, verified that the use of palette scarifier was extremely aggressive to the seeds, since, after being submitted to scarification, they did not germinate.

For the seeds of the class 3 , there was almost no variation among the lots. It is due to the fact that the occurrence of seeds without embryo is related to the production field, plant of origin or fertilization process. Therefore, since the seeds were achieved from a single crop, such similar values were expected.

The Pearson correlation coefficient ( $r$ ) was calculated between the germination achieved by the LERCAFÉ and Germination tests to verify the efficiency of the test. To illustrate the correlation found, a graphic was prepared presenting the values of both tests (Figure 2). The value of the Pearson correlation (r) is presented along with the graphic. The results achieved demonstrate that there was a positive and significant correlation between the results of the tests. The correlation significant value $(r=0,9550)$ demonstrates that the use the LERCAFÉ test is very important for the detection and quantification of this kind of damage, since, in the treatments in which a higher percentage of seeds with mechanical damage was detected (lots 3 and 4), it was also observed a significant decrease in the germination. This characteristic (high correlation between the values achieved in the germination and LERCAFÉ tests) was also observed by Zonta et al. (2008) and Zonta et al. (2009), studying different kinds of damage in coffee seeds.

Table 1. Results of the LERCAFÉ and Germination tests for lots of coffee plants with different percentages of mechanically damaged seeds.

\begin{tabular}{|c|c|c|c|c|}
\hline \multirow{2}{*}{ Lot* } & \multirow{2}{*}{ Germination test (\%) } & \multicolumn{3}{|c|}{ LERCAFÉ Test (\%) } \\
\hline & & Class 1 (Germinable) & Class 2 & hinable) \\
\hline 1 & $91 \mathrm{a}^{1}$ & $97 \mathrm{a}$ & 0 & 3 \\
\hline 2 & $90 \mathrm{a}$ & $92 \mathrm{~b}$ & 6 & 2 \\
\hline 3 & $85 \mathrm{~b}$ & $89 \mathrm{c}$ & 10 & 1 \\
\hline 4 & $81 \mathrm{~b}$ & $84 \mathrm{~d}$ & 14 & 2 \\
\hline $\mathrm{CV}(\%)$ & 2,2582 & 1,537 & 15,130 & 30,716 \\
\hline
\end{tabular}

1 Averages followed by the same letter in the column do not present significant difference by the Tukey test at $5 \%$ of probability. * Lot 1: $0 \%$ of damaged seeds; Lot 2: $5 \%$ of damaged seeds; Lot 3: $10 \%$ of damaged seeds and Lot 4: $15 \%$ of damaged seeds. 


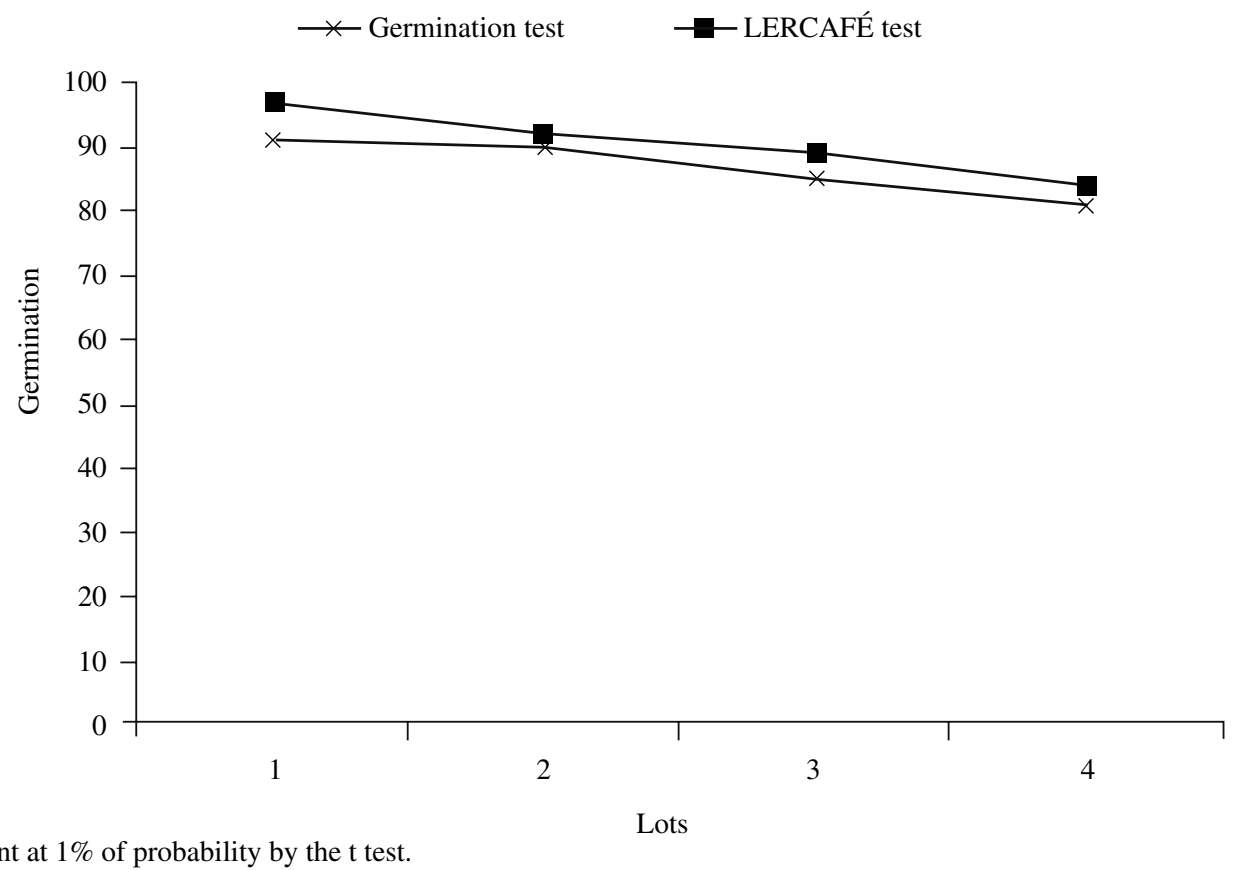

**significant at $1 \%$ of probability by the t test.

Figure 2. Results of the LERCAFÉ and Germination tests for lots of coffee with different percentage of damaged seeds, and the coefficient of correlation ( $r$ ) between the tests.

\section{Conclusions}

- The LERCAFÉ test is efficient to characterize mechanical damage in coffee seeds;

- Mechanical damage was characterized by a breach in the embryo region and/or in the region opposed to the embryo, with a green stain in the edges of these breaches;
- Lots of seeds mechanically damaged presented a sharp decrease in their germination power.

\section{Acknowledgements}

\section{To CNPq for financial support.}

\section{References Cited}

Araújo, E.F.; Reis, L.S.; Meireles, R.C.; Serrano, L.A.S. 2004 Efeito da danificação mecânica e da remoção manual do pergaminho sobre a emergência de plântulas de Coffea arabica $\mathrm{L}$. Revista Brasileira de Armazenamento. Viçosa, n.8, p.1-5.

Battisti, A.; Cantini, R.; Feci, E.; Frigimelica, G.; Guido, M.; Roques, A.

2000 Detection and evaluation of seed damage of cypress, Cupressus semprevirens L. Seed Science and Technology, Zurich, v.28, n.3, p.729-738.

Bewley, J.D.; Black, M.

1994 Seeds physiology of development and germination. 3.ed. New York: Plenum Press, 445p.

Brasil. Ministério da Agricultura e Reforma Agrária.

1992 Regras para análise de sementes. Brasília: SNDA/ DNDV/CLAV, 365p.

Carvalho, N.M.; Nakagawa, J.

2000 Sementes: ciência, tecnologia e produção. 3.ed. Campinas: Fundação Cargill, 424p.
Coutinho, A.C.

1984 Efeito da velocidade e região de impacto e do tempo de armazenagem de sementes de soja (cultivar UFV-5). 1984. 43 f. (Dissertação Mestrado). Universidade Federal de Viçosa, Viçosa.

Fagundes, A.V.; Rosa, S.D.V.F.; Ribeiro, F.L.F.

2009 Aceleração da formação de mudas de Coffea arábica L., cultivar "Topázio" em função da retirada do pergaminho. Revista Brasileira de Armazenamento, Especial Café, n.11, p.1-6.

Flor, E.P.O.; Cicero, S.M.; França Neto, J.B.; Krzyzanowski, F.C. 2004 Avaliação de danos mecânicos em sementes de soja por meio da análise de imagens. Revista Brasileira de Sementes, v.26, n.1, p.68-76.

Gomes, F.P.

2000 Curso de estatística experimental. 14 ed., Piracicaba-SP, $477 \mathrm{p}$.

Machado, C.F.

2002 Metodologia para a condução do teste de germinação e utilização de raios-X para a avaliação da qualidade de 
sementes de aroeira-branca (Lithraea molleoides (Vell.) Engl.). 2002. 51f. Tese (Mestrado) - Escola Superior de Agricultura “Luiz de Queiroz", Universidade de São Paulo, Piracicaba.

Marcos Filho, J.; Cícero, S.M.; Silva, W.R.

1987 Avaliação da qualidade das sementes. Piracicaba:FEALQ, $230 \mathrm{p}$.

Menezes, N.L.

2007 Testes rápidos para a determinação da qualidade das sementes. Acesso em 30/01/2007 as 15:05 http://www. ufsm.br/sementes/trapidos.htm

Oliveira, L.M. de.

2000 Avaliação da qualidade de sementes de canafístula (Peltophorum dubium (Sprengel) Taubet) pelos testes de germinação, tetrazólio e raios-X. 2000. 111f. Tese (Mestrado) -Universidade Federal de Lavras, Lavras.
Reis, L.S.

2004 Lercafé: novo teste para estimar a germinação de sementes de cafeeiro (Coffea arabica L.). 2004. 57 f. (Dissertação Mestrado). Universidade Federal de Viçosa, Viçosa.

Vieira, M.G.G.C.; Guimarães, R.M.; Pinho, E.V.R.V.; Guimarães, R.J.; Oliveira, J.A.

1998 Testes rápidos para determinação da viabilidade e da incidência de danos mecânicos em sementes de cafeeiro. Lavras: UFLA, 34p. Boletim Agropecuário, 26.

Zonta, J.B.; Araujo, E.F.; Araujo, R.F.; Reis, M.S.

2008 Uso do teste Lercafé para a caracterização de danos em sementes de cafeeiro. Pesquisa Agropecuária Brasileira, v.43, n.11, p.1601-1607.

Zonta, J.B.; Araujo, E.F.; Araújo, R.F.; Reis, M.S.; Lima, J.S. 2009 LERCAFÉ test for the assessment of coffee seed quality during storage. Seed Science and Technology, v.37, n.1, p. $140-146$ 